\title{
The Effectiveness of Monetary Policy Transmission Under Capital Inflows: Evidence from Asia
}

Sonali Jain-Chandra and D. Filiz Unsal 


\title{
IMF Working Paper
}

Asia and Pacific Department

\section{The Effectiveness of Monetary Policy Transmission Under Capital Inflows: Evidence from Asia}

\author{
Prepared by Sonali Jain-Chandra and D. Filiz Unsal ${ }^{1}$ \\ Authorized for distribution by Thomas Rumbaugh
}

November 2012

\section{This Working Paper should not be reported as representing the views of the IMF. The views expressed in this Working Paper are those of the author(s) and do not necessarily represent those of the IMF or IMF policy. Working Papers describe research in progress by the author(s) and are published to elicit comments and to further debate.}

\begin{abstract}
The effectiveness of the monetary policy transmission mechanism in open economies could be impaired if interest rates are driven primarily by global factors, especially during periods of large capital inflows. The main objective of this paper is to assess whether this is true for emerging Asia's economies. Using a dynamic factor model and a structural vector autoregression model, we show that long-term interest rates in Asia are indeed predominantly driven by global factors. However, monetary policy transmission mechanism remains effective in the region, as it operates predominantly through short-term interest rates. Nevertheless, the monetary transmission mechanism, though effective, is somewhat weaker in Asia during the periods of surges in capital inflows.

JEL Classification Numbers: E43; E52; F41

Keywords: Monetary policy transmission, capital flows, dynamic factor model, structural VAR Author's E-Mail Address: sjainchandra@,imf.org; dunsal@,imf.org

\footnotetext{
${ }^{1}$ A part of this analysis was featured in April 2011 Regional Economic Outlook of Asia and Pacific Department of the IMF. We are grateful to Vivek Arora, Roberto Cardarelli, and Tom Rumbaugh for valuable comments and suggestions. We also thank the seminar participants of the Bank of Thailand, KIEP-IMF Joint Conference 2011, and Asia and Pacific Department of the IMF for insightful discussions and comments. Souvik Gupta and Ryan Wu provided excellent research assistance.
} 


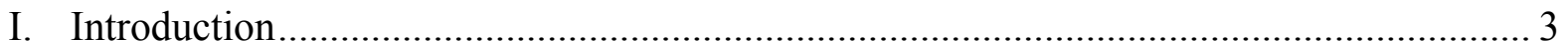

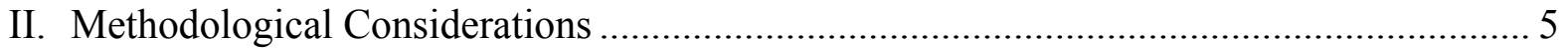

A. Generalized Dynamic Factor Model ................................................................... 6

B. Structural Vector Autoregression ......................................................................... 7

III. Are Local Bond Yields in Asia Driven by External or Domestic Factors?-Empirical

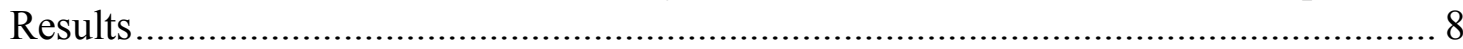

IV. Which Interest Rates Matter More for Monetary Transmission Mechanism? ............... 12

V. The Monetary Transmission Mechanism Under Large Capital Flows.......................... 13

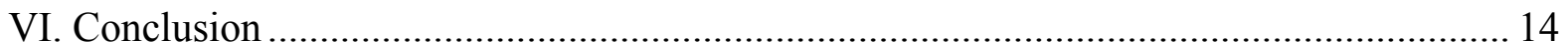

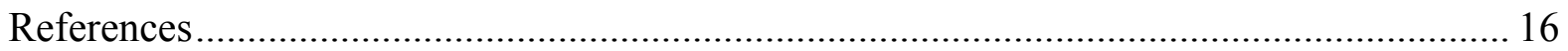

Figures

1. Secondary Market Yield of 10-Year Government Bond …........................................ 6

2. The Estimated Common Factor and U.S. 10-Year Bond Yield and the VIX ................... 9

3. Contributions of U.S. 10-Year Yield and VIX to Estimated Common Factor ................ 10

4. Variance Decomposition of Domestic 10-Year Yield by Sources During

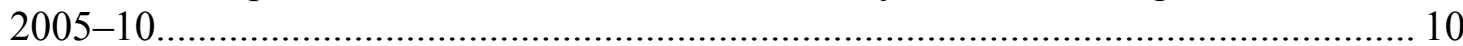

5. Contribution of U.S. Long-Term Interest Rates to Variance of Domestic

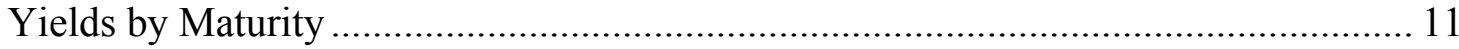

6. Importance of U.S. Interest Rate and Capital Account Openness ............................... 11

7. Variance Decomposition of Industrial Production in Response to Shocks to Domestic

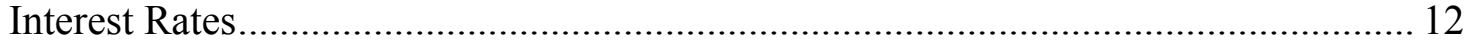

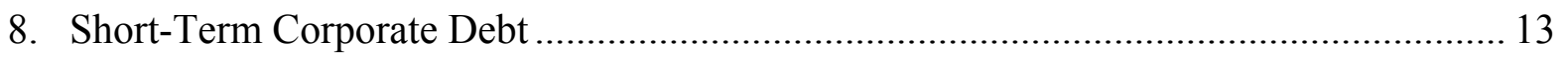

9. Effect of Capital Flows on Monetary Transmission Mechanism ................................ 14 


\section{INTRODUCTION}

The monetary transmission mechanism refers to how policy-induced changes in the short-term interest rate affect real variables such as investment, output, and employment. It is implicit in this definition that changes in short-term policy rates have a significant impact on the other interest rates that matter for economic activity, such as long-term interest rates. However, the link between the short-term policy rate and longer-term rates could be impaired in economies with open financial accounts as international factors also play a role in determining returns on domestic financial assets. Indeed, the decoupling of short-and long-term interest rates in open emerging markets is a well-known stylized fact over the last decade (Pradhan and others, 2011).

This decoupling of short-term policy rates and long-term interest rates has an important bearing on the effectiveness of monetary policy in influencing economic activity. If the transmission from short-term policy rate to long-term interest rates is not strong or timely, the impact of monetary policy on the real economy would be consequently limited. This is particularly important for Asian emerging market economies, which continue to progress in developing capital markets, especially bond markets. The development of capital markets could make long term yields in the region more sensitive to global developments. ${ }^{1}$ As longterm rates in the region could be increasingly driven by global factors, providing macroeconomic and financial stability could become more difficult for Asian policymakers.

The weak link between short-term policy rates and long-term interest rates is not only an emerging market phenomenon. In the United States, the small impact of changes in the target for the federal funds rate on long-term rates in the mid-1990s was referred to as a "conundrum" by the former Federal Reserve Chairman Alan Greenspan. Kim and Wright (2005) and Cochrane and Piazzesi (2006) explained the decline in U.S. long-term yields with the fall in risk premium. Backus and Wright (2007) suggested that a more stable macroeconomic and financial environment, including more predictable monetary policy, could have also contributed to the decline in U.S. long-term interest rates.

More prominently, Bernanke $(2005,2007)$ argued that, with integrated financial markets, global forces could have a role to play in explaining long-term interest rates. Along these lines, Craine and Martin (2009) and Warnock and Warnock (2009) pointed out that increased foreign demand lowered U.S. yields in 2004-05. ${ }^{2}$ Focusing on a large set of countries, Diebold, Li, and Yue (2008) and Byrne, Fazio, and Fiess (2010) found that global factors can explain a large fraction of the yield curve, especially at the longer end. Moreno (2008), Ciarlone and others (2009), and Pradhan and others (2011) also provided evidence on the key

\footnotetext{
${ }^{1}$ See Felman and others, 2011.

${ }^{2}$ Bernanke and others (2004) also found evidence that Japanese intervention in currency markets pushed the ten year bond yield down.
} 
role of global factors in determining long-term interest rates in a number of emerging markets. Moreno (2008) also finds an evidence for an increasing role played by global factors over the last decade.

During the periods of large capital inflows, the link between short-term policy rates and long-term rates could be particularly weak. An increase in the policy rate would have only a limited impact on the long-term rates if banks and other financial institutions can get cheap financing from abroad in large quantities. By depressing domestic long-term yields, the surge in capital inflows could potentially impair policymakers' ability to tighten monetary policy. Indeed, the surge of capital flows to emerging market economies, after the global crisis, has raised concerns about the effectiveness of the monetary policy in these economies, especially in Asia, where rapid growth after the global crisis had been accompanied by the emergence of pockets of overheating in both goods and asset prices.

Against this background, this paper focuses on the strength of the monetary policy transmission mechanism in emerging Asia, particularly in a context of large capital inflows. We focus on two interrelated but distinct aspects of the "transmission mechanism:" (i) the impact of changes in short-term policy rates on long-term interest rates; and (ii) the impact of changes in interest rates of different maturities on economic activity.

The main questions this paper will seek to answer are as follows:

- What determines market interest rates in Asia? What is the relative contribution of global versus domestic factors in driving yield curves in the region?

- $\quad$ Are short-term or long-term interest rates more important in driving economic fluctuations in the region?

We use a Generalized Dynamic Factor Model (GDFM) and Structural Vector Autoregression (SVAR) models in our analysis. In the GDFM, we estimate the unobserved common component of long-term bond yields in Asia and associate this common component with the foreign interest rate (proxied by the U.S. long-term rates) and global risk aversion (measured by the VIX). We then use SVAR models to focus on the structural relationship between the domestic long-term interest rate, domestic policy rate, and foreign interest rates, as well as between interest rates and economic activity. We focus on eight emerging Asian economies, namely, China, India, Indonesia, Korea, Malaysia, the Philippines, Taiwan Province of China, and Thailand over the last decade. ${ }^{3}$

The main results of this paper are threefold. First, we find that global factors are important drivers of long-term interest rates in Asia. About 40 percent of the changes in the long-term rates can be explained by external factors. Moreover, U.S. interest rates are a more important

\footnotetext{
${ }^{3}$ Hong Kong SAR and Singapore are excluded because their nominal anchor for monetary policy is not the interest rate but the exchange rate.
} 
determinant of changes in long-term yields than short-term domestic interest rates in Asia. Second, monetary policy in the region is still effective, as the interest rate channel of transmission mechanism in Asia largely relies on short-term interest rates. Changes in the short-term policy rates account for a much more significant variation in output than longer-term rates in the region. Third, while large capital inflows weaken the link between the short-term policy rate and lending rates by about a third, the transmission mechanism still remains powerful.

This paper is structured as follows: In the next section, we provide a discussion on the methodologies; Section 3 presents the results of the empirical analysis on the role of global and domestic factors in driving long-term interest rates in Asia; Section 4 investigates the relative importance of short-term versus long-term interest rates in driving economic activity; Section 5 analyzes the impact of large capital inflows on the transmission of changes in the short-term interest rates to longer-term rates; and Section 6 concludes.

\section{Methodological Considerations}

In principle, long-term interest rates in an open economy can depend on a host of factors, both domestic and global. Among the former, the current short-term rate, expectations of future policy rates, term premia, and inflation expectations would potentially have an impact on long-term bond yields. Among global factors, foreign interest rates, expected exchange rate changes, and risk appetite of foreign investors are likely to influence long-term yields. Moreover, the contribution of these factors is expected to vary with the degree of financial integration.

Figure 1 suggests that there seems to be common movements among yields on Asian 10-year bonds, which could be related to the movements in U.S. 10-year government bond yields. To formally assess the relative importance of domestic versus foreign factors in determining long-term interest rates in Asia, two methodologies are used in this paper: a GDFM and a SVAR model. 


\section{Figure 1. Secondary Market Yield of 10-Year Government Bond (In percent)}

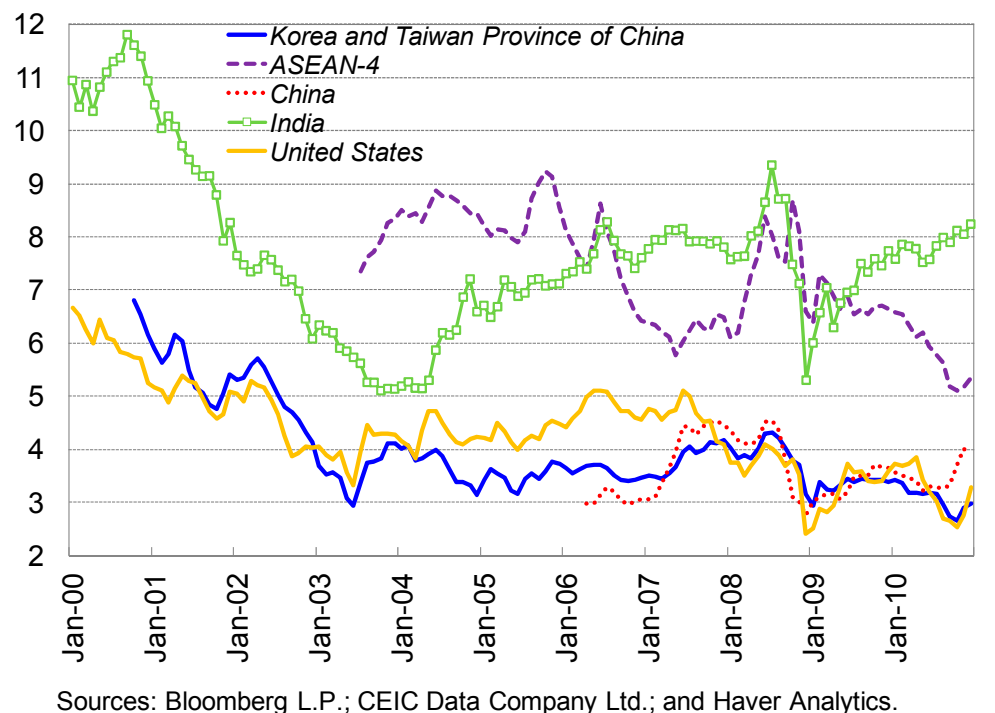

\section{A. Generalized Dynamic Factor Model}

The GDFM provides an estimation of the unobserved common factor among a given set of sample elements, following Forni and others (2005). The analysis assumes that there exist unobservable latent variables: (i) "common factors" that contemporaneously influence more than one data point; and (ii) "specific factors" that influence only one of them. Therefore, the factor analysis provides a quantitative assessment of "commonality" among variables, which are in turn related to the global factors. Following the estimation of this common component, its determinants are analyzed, including the VIX, foreign interest rates, and the slope of the U.S. yield curve, as a proxy for foreign growth prospects.

Let $y^{j}$ be the data set used for the $j$-th country:

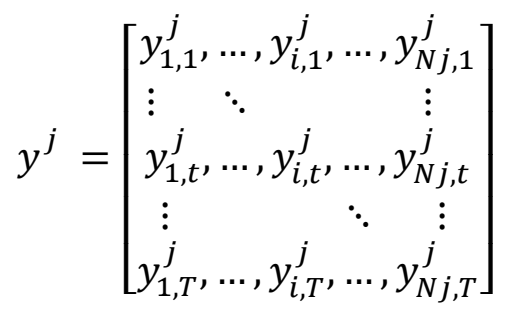

The latter is a balanced panel data set comprised of yields on government bonds of different maturities.

In the GDFM, each observation $\left(y_{i t}^{j}\right)$, for every time series $i=\left\{1, \ldots, N^{j}\right\}$ and country $\mathrm{j}=\{1, \ldots, J\}$, and across time $\mathrm{t}=\{1, \ldots, \mathrm{T}\}$, is composed of two mutually orthogonal parts, an idiosyncratic component and a common component. The common component here would correspond to the variation in yields that is not directly linked to the specific macroeconomic 
characteristics of the country but to developments in the global economic and financial system. This implies that each data point can be represented as follows:

$$
y_{i, t}^{j}=\chi_{i, t}^{j}+\xi_{i, t}^{j}=b_{i}^{j}(L) f_{t}^{j}(L)+\xi_{i, t}^{j}
$$

where $\chi_{i, t}^{j}$ is a common component driven by a small number $\left(q_{j}\right)$ of common shocks or factors, and each element of $b_{i}^{j}(L)=\left[b_{i, 1}^{j}(L), \ldots, b_{i, q j}^{j}(L)\right]$ is a row vector of the lag polynomials for the $\mathrm{i}=\left\{1, \ldots, \mathrm{N}^{\mathrm{j}}\right\}$ variables. The idiosyncratic component is summarized by $\xi_{i, t}^{j}$, reflecting $N^{j}$ variable-specific shocks. The common factor $\left(\mathrm{f}_{\mathrm{t}}^{\mathrm{j}}\right)$ needs to be estimated through a dynamic principal component analysis. ${ }^{4}$ The first step involves estimating $\mathrm{f}_{\mathrm{t}}^{\mathrm{j}}=$ $\left(\mathrm{f}_{1, \mathrm{t}}^{\mathrm{j}}, \ldots, \mathrm{f}_{\mathrm{qj}, \mathrm{t}}^{\mathrm{j}}\right)^{\prime}, \mathrm{a}_{\mathrm{j}}$-dimensional column vector of common factors across time, for each country. In our analysis, $q_{j}=1 \forall j \in\{1, \ldots, J\}$, and $f_{t}^{j}$ represent the estimated unobserved "common" factor, which represents the impact of global factors on bond yields. ${ }^{5}$

One potential drawback of any factor model is that the common factor is an unobservable statistical construct and hence the method is silent about what drives the estimated common factor. To overcome this difficulty, we construct a simple VAR model with global risk aversion (measured by the VIX), U.S. 10-year government bond yields, and the estimated common factor (in that ordering).

\section{B. Structural Vector Autoregression}

A SVAR model is also used to estimate the relationship between the domestic long-term interest rate, domestic policy rate, and foreign interest rates. ${ }^{6}$ The following system of equations is estimated:

$$
Y_{t}=A_{0}+\sum_{i=1}^{p} A_{i} Y_{t-i}+B Z_{t}+\varepsilon_{t}
$$

Where $Y$ is a vector of endogenous variables, and includes expected changes in exchange rates, changes in capital flows, GDP growth, and inflation expectations. ${ }^{7} Z$ refers to a vector

\footnotetext{
${ }^{4}$ For a more detailed background discussion, see Forni and Lippi (2001).

${ }^{5}$ In principle, there could be more than one "common factor" within a set of data. We determine the number of common factors using the method outlined in Hallin and Liška (2007). As a complementary method, we also look at the percentage of the variance explained by the common factors. Although there is no general rule about what percentage make a factor significant, in our case, adding another common factor brings only a negligible increase in explained variance.

${ }^{6}$ Previous work on a large set of Asian and non-Asian emerging market countries using VARs has found that foreign interest rates have a larger impact on domestic long-term rates than the domestic policy rate (see Moreno, 2008).

${ }^{7}$ Expected exchange rate changes are based on consensus forecasts of exchange rate movements.
} 
of exogenous variables, specifically including the VIX and foreign demand. Data are from January 2000 to November 2010 and are first differenced to ensure stationarity. The lags are chosen using the standard information criterion.

The SVAR is identified using the Choleski decomposition of the variance-covariance matrix of the residuals. The ordering of the model follows other papers in the literature, including Christiano, Eichenbaum, and Evans (1996) and Kim (1999). The identifying assumption is that output reacts more slowly than financial variables and is contemporaneously more exogenous. In the ordering, output is followed by inflation expectations, interest rates, and exchange rates. The policy rate is assumed to be contemporaneously more exogenous than market rates, because the latter are assumed to react to the policy rate.

The robustness of the results is tested in various ways. First, using generalized impulses also leads to similar result on the drivers of long-term yields in Asia. Second, the results presented in this paper are based on the U.S. 10-year yield, which correlates well with the estimated common factor. However, a robustness check using a global interest rate (average of the United States, the European Union, and Japan) does not change the nature of the findings.

A second set of VARs is used to assess the relationship between output and interest rates across the yield curve in Asia, similar to Christiano, Eichenbaum, and Evans (1996) and Lange (2005). In particular, the responses of output to shocks in interest rates of different maturities are examined. The variables in the model include 3-month (proxy for short-term rate), 1-year, and 10-year government bond yields, industrial production (measure of output), inflation expectations, exchange rate changes, and foreign demand. The variables in the VAR are ordered so that output is assumed to be contemporaneously the most exogenous (as above), whereas interest rates are considered more endogenous as they react more rapidly to changes in nominal variables. To identify the VAR, we assume that interest rates are ordered in terms of maturity (Lange, 2005), so that the yields of shorter maturity affect the longerterm yields contemporaneously. The relative importance of shocks to different interest rates for aggregate demand is shown by the forecast error variance decompositions.

\section{ARE LOCAl Bond YIELDS IN ASIA DRIVEN bY EXTERNAL OR DOMESTIC FACTORS?-EMPIRICAL RESULTS}

The relative importance of domestic versus foreign factors in determining long-term interest rates in Asia is assessed using the two methodologies outlined in the previous section: a GDFM and a SVAR.

The estimated common factor from Asian long-term bond yields exhibits a high degree of comovement with global financial variables, suggesting the potential for spillovers to local yields from movements in global interest rates and risk aversion. 
- Indeed, Figure 2 illustrates that changes in the estimated common factor is highly correlated with the changes in the interest rate on 10-year U.S. government bonds (correlation coefficient of 0.65), whereby an increase in U.S. long-term yields is associated with an accompanying increase in domestic long-term yields in Asia.

- In addition, the estimated common factor is also associated with changes in the global risk aversion (measured by the VIX), with correlation coefficients of -0.45 . This partially reflects the lower yields in the US economy in the aftermath of the global crisis. During this period, global risk aversion was on the rise, but U.S. long term interest rates were kept lower in response to the dramatic collapse in the economy and financial markets. If the impact of the lower U.S. government rates on the Asian yields suppresses the impact of the VIX, the correlation between the estimated common factor and the VIX could be negative. In fact, if we exclude the crisis period, the correlation is about positive 0.4.

Figure 2. The Estimated Common Factor and U.S. 10-Year Bond Yield and the VIX

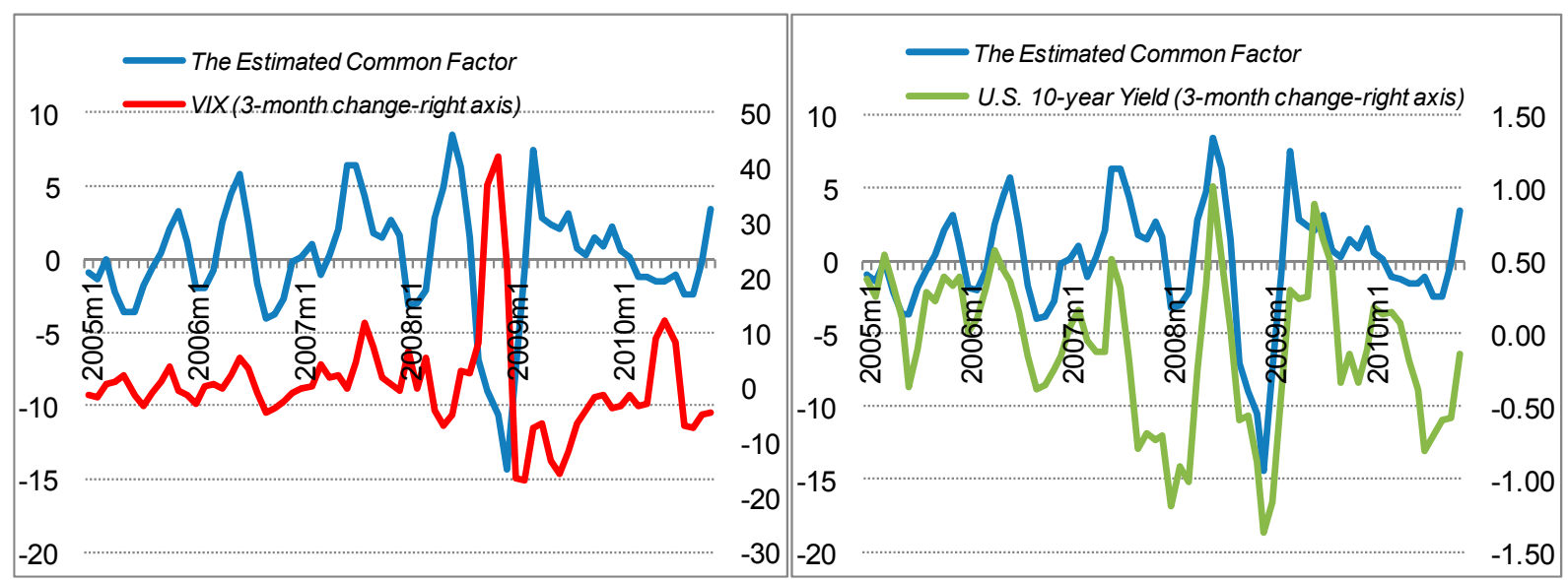

Source: Authors' calculations.

The main finding is that a large proportion of the change in long-term yields in Asia over the last decade can be explained by global factors. The estimated common factor model shows that about 40 percent of the variation in long-term Asian bond yields on average over the last 10 years can be explained by the "common factor." A more rigorous analysis using a VAR is used to assess the contribution of various global variables in explaining the dynamics of the estimated common factor. This analysis reveals that in fact U.S. long-term interest rates and the VIX explain a large share of the variation in this estimated common factor of Asian bond long-term (10 year) bond yields (35 percent and 25 percent, respectively; Figure 3 ). Also, as expected, the contributions of foreign interest rates and global risk aversion increase with maturity, consistent with the observation that foreign investors have been more active at the longer end of the yield curve (Peiris, 2010). At the short-end of the yield curve, domestic factors play a more prominent role. 


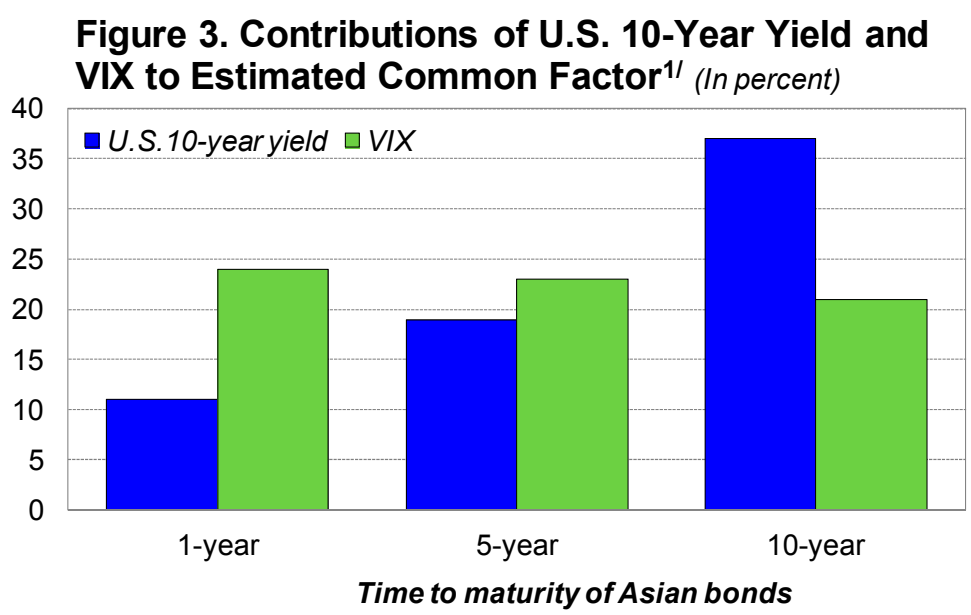

Sources: CEIC Data Company Ltd; and authors' calculations.

1/Variance decomposition of the common factor over 10-quarters.

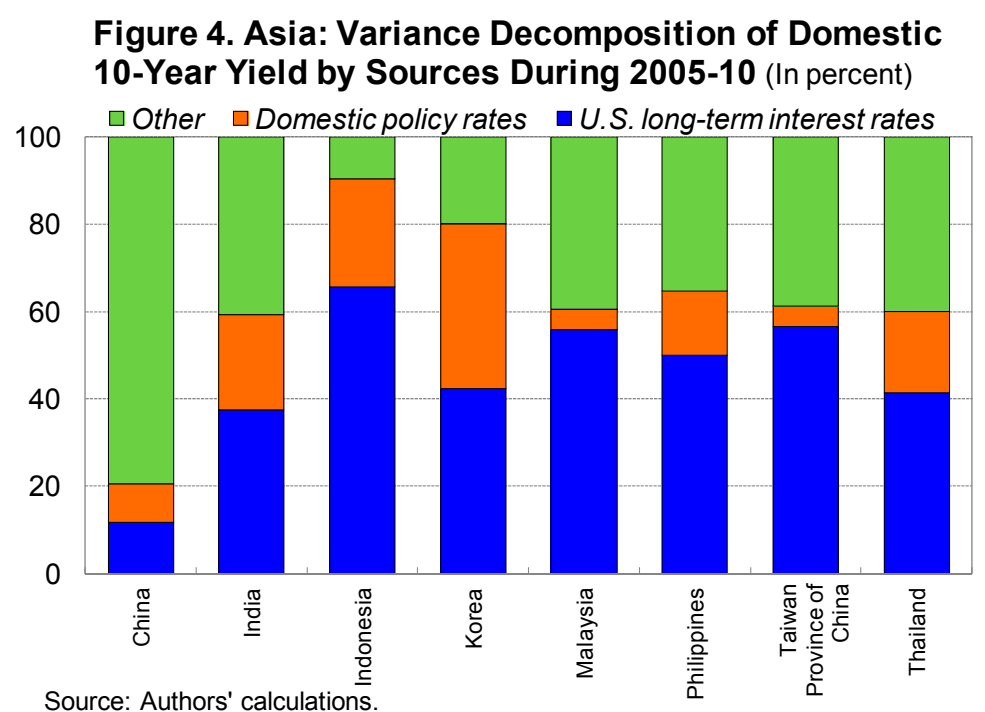

The analysis also shows that U.S. interest rates are an important determinant of changes in long-term yields for a number of Asian economies. In some cases, they are more important drivers than short-term domestic interest rates. The response of domestic long-term yields to shocks to U.S. yields and domestic policy rates is assessed within a SVAR model that also includes inflation expectations, exchange rate changes, global risk aversion, and GDP growth. ${ }^{8}$ The results suggest that, on average across Asia, about half of the variation in longterm yields can be attributed to shocks to U.S. long-term interest rates (Figure 4). For shorterterm yields (one year), the contribution from U.S. interest rates is lower, and domestic variables matter more (Figure 5).

\footnotetext{
${ }^{8}$ Our results are robust to controlling for terms of trade and the exchange rate regime. The external factor may have a role also in determining neutral interest rates. For a related discussion, see Magud and Tsounta (2012).
} 
The contribution of U.S. interest rates to domestic bond yields varies noticeably across Asia. In particular, the contribution is smaller in countries that are less financially integrated and have relatively less open capital accounts, such as India and China. As expected, the contribution is higher in countries with a large foreign presence in domestic government bond markets (such as Indonesia and Malaysia). ${ }^{9}$ Indeed, plotting the contributions to Asian bond yields from the U.S. interest rate (from the SVAR model) together with an index of capital account openness (as measured by the Chinn-Ito index; see Chinn and Ito, 2008) shows that countries that are more financially integrated tend to be more exposed to the U.S. interest rate cycle (Figure 6).

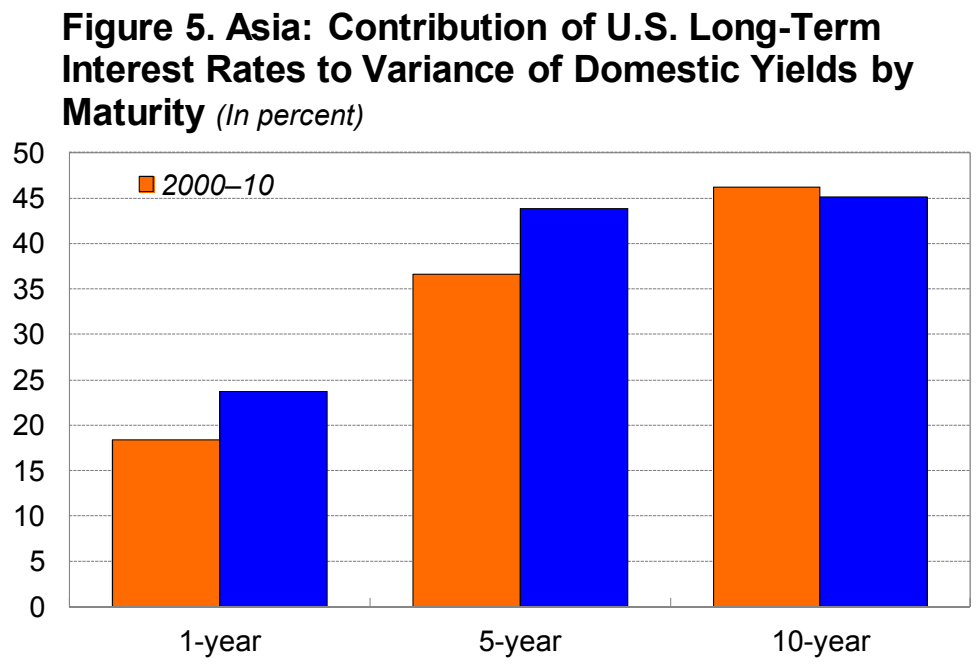

Source: Authors' calculations.

Figure 6. Importance of U.S Interest Rate and

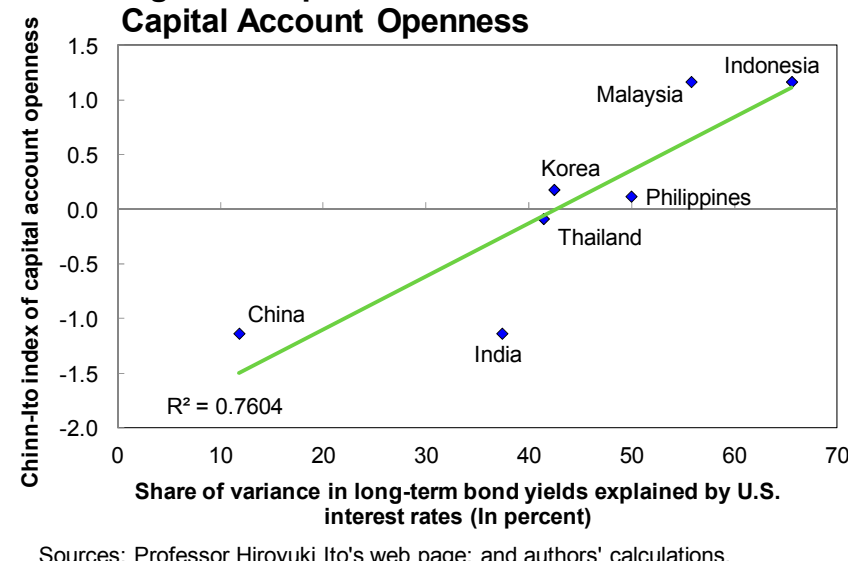

${ }^{9}$ Indeed, the increasing foreign participation in Asian bond markets appears to explain to a large extent the correlation between U.S. interest rates and Asian long-term yields. See IMF (2011) and Pradhan and others (2011). 


\section{WHICH INTEREST RATES MATTER MORE FOR MONETARY TRANSMISSION MECHANISM?}

The previous section concluded that long-term interest rates in Asia are determined by global factors to a large extent. This, however, does not necessarily imply that policy-induced changes in the short-term interest are ineffective in influencing economic activity. This is because it is not obvious a priori whether it is the long-term interest rate that matters for economic decisions, rather than short-term interest rates.

In fact, notwithstanding the important role of long-term rates in monetary transmission in other parts of the world, we find that the interest rate channel in Asia works mostly through short-term interest rates. A vector autoregression model shows that after 1 year, changes in 3 -month interest rates account for about 25 percent of the average variation in output across Asian emerging economies, compared with about 5 percent explained by changes in 10 -year rates (Figure 7). ${ }^{10}$ The role of the short-term policy rate in driving economic activity is even bigger in a shorter horizon of 6 months, about 30 percent, relative to the role of long term interest rates, about 3 percent.

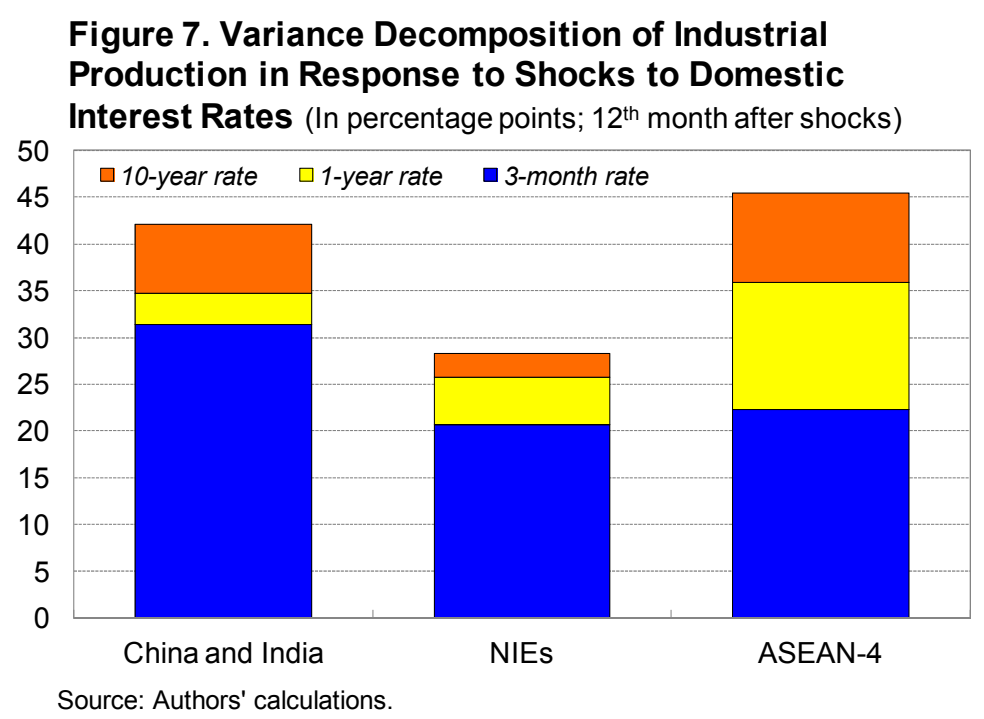

The relatively greater importance of short-term rates in driving the real economy may be explained by bank loans to businesses in Asia being often priced in reference to interbank rates with short-term maturities, typically three months. ${ }^{11}$ This is partly due to the fact that the maturity of the loans in the region tend to be shorter (three to five years), perhaps due to

\footnotetext{
${ }^{10}$ The remainder of the variation in output is explained by foreign demand, inflation expectations, and exchange rate changes.

${ }^{11}$ Garcia-Herrero and Remolona (2008) present results of a survey among Asian economies on the relative role of interest rates of different maturities in determining the lending rates on several credit components, such as consumer credits and corporate credit. Their results support our analysis in that the reference interest rate for most of the bank credit appears to be short-term interest rates.
} 
the common presence of high risk perception over the longer term. For example, for most countries in the sample, more than half of corporate debt is short-term, and the bulk of mortgages is at variable rates and also priced in reference to short-term rates (Figure 8). ${ }^{12}$

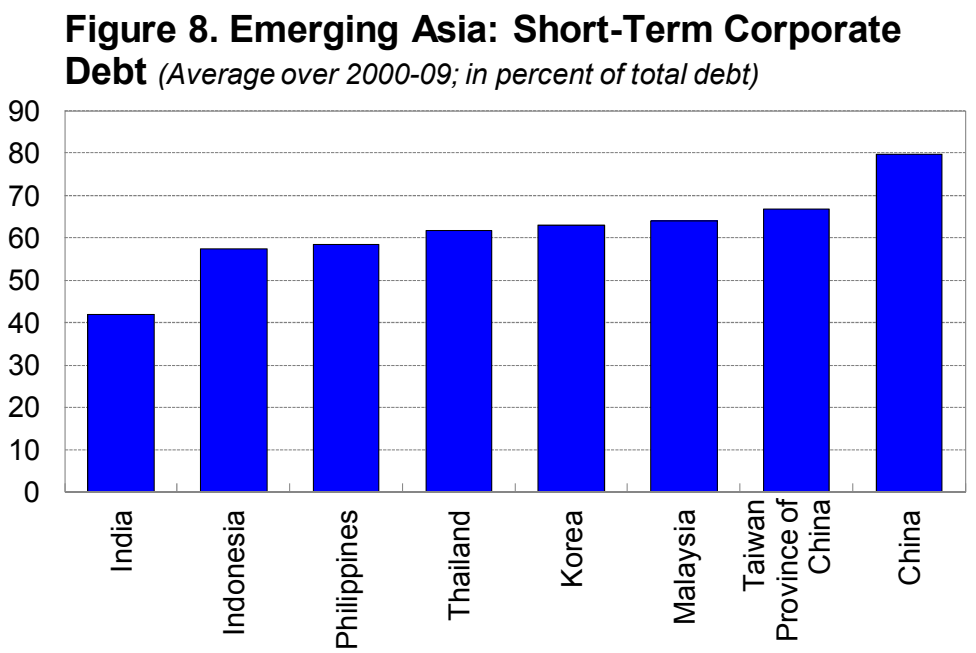

Source: IMF, Corporate Vulnerability Utility database.

\section{The Monetary Transmission Mechanism Under LARge CAPITAL Flows}

Although still effective, the interest rate channel of transmission may be somewhat weaker in periods of large and volatile capital inflows. If easy external financing conditions allow borrowing at a lower interest rate abroad, the loan rates could become insensitive to the changes in the policy rate for two reasons. First, large inflows may lower the risk premium, blunting the impact of monetary tightening on lending rates. Second, if foreign capital is abundant, banks may choose not to raise lending rates when domestic monetary policy is tightened.

To assess whether the pass-through from policy rates to market interest rates in Asia is different when an economy is facing large capital inflows, a fixed-effects panel model is estimated that regresses three-month rates on policy rates and lags of both. ${ }^{13}$ We estimate the model for the entire sample and episodes under a "surge in capital inflows." Following the methodology outlined in IMF (2007) and IMF (2011), an episode of large net private capital flows for a particular country is a period of two or more quarters during which these flows (as a share of GDP) are significantly larger (1 standard deviation) than their historical trend or above the 75 th percentile of their distribution over the whole sample. ${ }^{14}$ Other factors that

\footnotetext{
${ }^{12}$ See Mohanty and Turner (2008).

13 This is in line with the model specification presented in IMF (2010), although estimated as a panel rather than country by country, owing to lack of sufficient capital inflow episodes for certain countries. Robust standard errors are used to gauge statistical significance.

${ }^{14}$ On the basis of the definition above, 19 surges in net private capital inflows to Asia have occurred during the last 10 years. Most of these episodes (13) occurred before the global financial crisis. The episodes after the
} 
determine the pass-through from policy rates to market rates, such as the degree of competition within the banking sector, and financial market development and openness, are accounted for by including country-specific fixed effects in the model.

The analysis finds that large capital inflows weaken the link between changes in the policy rates and bank lending rates. On average across Asian economies, the short-term passthrough coefficients decline by about 40 percent, whereas the long-term pass-through coefficients decline by about 30 percent (Figure 9). However, the transmission from shortterm interest rate to lending rates is still strong, both in the short term and in the long term. The pass through coefficients even under large capital inflows are 0.3 in the short-term, and 0.6 in the long-term for the region.

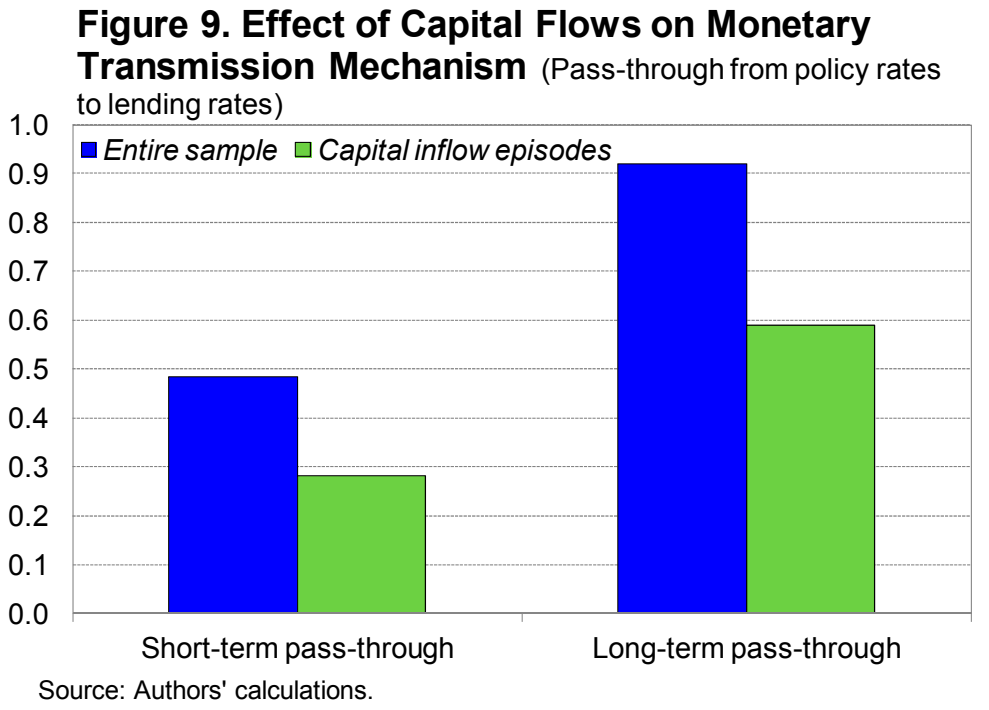

\section{CONCLUSION}

This paper focuses on the effectiveness of the interest rate transmission mechanism of monetary policy in emerging economies in Asia, in particular in the presence of globally integrated financial markets and mobile capital. The paper investigated the extent to which long-term interest rates in Asia are driven by global versus domestic factors. The analysis suggests that, indeed, long-term interest rates in Asia are determined by global factors to a large extent, including foreign interest rates and global risk aversion. However, this exposure to the global factors varies considerably across countries. As expected, the finding is that more financially open economies are more exposed to the global interest rate cycle.

However, does this mean that monetary policy is rendered ineffective in smoothing the business cycle, for instance by boosting activity during cyclical downturns? This paper then

global crisis averaged about 4 percent of GDP (compared with about 5 percent in the 1990s) and lasted only five quarters. See IMF (2011) for more details on the episodes of large capital inflows to Asia. 
investigates which interest rates matter most for influencing economic activity across Asia and finds that the concerns regarding the effectiveness of monetary policy are not acute in the region. The main finding is that the interest rate channel of the monetary transmission mechanism remains powerful, as it works mainly through short-term interest rates. Moreover, even in the face of large capital inflows, monetary policy in Asia remains effective at macroeconomic stabilization even though the pass-through is lower during such episodes.

Our findings have important implications for the conduct of monetary policy in the region during large capital inflows periods. In particular, we find that the policy interest rate remains a powerful tool in macroeconomic stabilization in Asia. Going forward, however, continued integration of regions' capital markets with the world economy could make external developments the dominant factor in determining domestic rates. Moreover, there could be constraints in the implementation of monetary policy when faced with large capital inflows; for example, tightening monetary policy could reinforce more inflows. Therefore, in the face of a surge in capital inflows, policymakers should remain ready to use other policy instruments such as macroprudential policies as a complement to appropriate macroeconomic policy settings. ${ }^{15}$

\footnotetext{
${ }^{15}$ See Unsal (2012) for a theoretical analysis on the use of macroprudential measures in helping monetary policy stabilize the economy under large capital inflows.
} 


\section{REFERENCES}

Backus, David, and J. Wright, 2007, "Cracking the Conundrum," Brookings Papers on Economic Activity 2007-1: 293-329 (Washington, D.C.).

Bernanke, B. S., V. R. Reinhart, and B. P. Sack, 2004, "Monetary Policy Alternatives at the Zero Bound: An Empirical Assessment," Brookings Papers on Economic Analysis, Vol. 2, pp. 1-100 (Washington, D.C.).

Bernanke, B. S., 2005, "The Global Saving Glut and the U.S. Current Account Deficit," Homer Jones Lecture, April 14.

_ 2007, "Global Imbalances: Recent Developments and Prospects," The Bundesbank Lecture, September.

Byrne, Joseph P., Giorgio Fazio, and Norbert Fiess, 2010, "Interest Rate Co-movements, Global Factors and the Long End of the Term Spread," Journal of Banking and Finance, Vol. 36, pp. 183-192.

Chinn, M. D., and H. Ito, 2008, “A New Measure of Financial Openness,” Journal of Comparative Policy Analysis, Vol. 10, No. 3, pp. 309-22 (September).

Christiano, L. J., M. Eichenbaum, and C. L. Evans, 1996, “The Effects of Monetary Policy Shocks: Evidence from the Flows of Funds," Review of Economics and Statistics, Vol. 78, pp. 16-34.

Ciarlone, Alessio, Paolo Piselli, and Giorgio Trebeschi, 2009, “Emerging Markets' Spreads and Global Financial Conditions," International Financial Markets, Institutions and Money Vol. 19, pp. 222-39.

Cochrane, J. H., and M. Piazzesi, 2006, "Decomposing the Yield Curve," (Chicago: University of Chicago).

Craine, R., V. Martin, 2009, "Interest rate conundrum," The B.E. Journal of Macroeconomics, Vol. 9 (contributions), Article 8.

Diebold, F. X., C. Li, and V. Yue, 2008, "Global Yield Curve Dynamics and Interactions: A Generalized Nelson-Siegel Approach," Journal of Econometrics, Vol. 146, pp. 351-63.

Felman, J., S. Gray, M. Goswami, A. Jobst, M. Pradhan, S. Peiris, and D. Seneviratne, 2011, "ASEAN5 Bond Market Development: Where Does It Stand? Where is It Going?" IMF Working Paper 11/137 (Washington: International Monetary Fund).

Forni, M., and M. Lippi, 2001, “The Generalized Dynamic Factor Model: Representation Theory," Econometric Theory, Vol. 17, pp. 1113-1141. 
Forni, M., M. Hallin, M. Lippi, and L. Reichlin, 2005, “The Generalized Factor Model: Onesided Estimation and Forecasting," Journal of the American Statistical Association 100, pp. 830-840.

García-Herrero, A., and E. Remolona, 2008, "Managing Expectations by Words and Deeds: Monetary Policy in Asia and the Pacific,” BIS Working Papers No. 47 (Basle: Bank of International Settlement).

Hallin, M., and R. Liška, 2007, "Determining the Number of Factors in the Generalized Factor Model," Journal of the American Statistical Association, Vol. 102, pp. 603617.

International Monetary Fund, 2007, "Managing Large Capital Inflows," in World Economic Outlook, World Economic and Financial Surveys (Washington, October).

— 2010, "Recent Developments and Main Themes," Regional Economic Outlook: Asia and Pacific (Washington, April).

— 2011, "Capital Flows to Asia: Comparison with Previous Experience and Monetary Policy Options," Regional Economic Outlook: Asia and Pacific (Washington, April).

Ito, Hiroyuki, 2012, “The Chinn-Ito Index," Available via internet: http://web.pdx.edu/ ito/Chinn-Ito website.htm

Kim, D. H., and Wright, J. H., 2005, “An Arbitrage-Free Three-Factor Term Structure Model and the Recent Behavior of Long-Term Yields and Distant-Horizon Forward Rates," Finance and Economics Discussion Series 2005-33 (Washington: Board of Governors of the Federal Reserve System, August).

Kim, S., 1999, "Do Monetary Policy Shocks Matter in the G-7 Countries? Using common Identifying Assumptions about Monetary Policy Across Countries," Journal of International Economics, Vol. 48, pp. 387-412.

Lange, R., 2005, "Determinants of the Long-Term Yield in Canada: An Open Economy VAR Approach," Applied Economics, Vol. 37, pp. 681-93.

Magud, N. E. and E. Tsounta, 2012, “To Cut or Not to Cut? That is the (Central Bank's) Question: In Search of the Neutral Interest Rate in Latin America", IMF Working Paper 12/243 (Washington: International Monetary Fund).

Mohanty, M. S., and P. Turner, 2008, "Monetary Policy Transmission in Emerging Market Economies: What is New?" BIS Papers chapters, in Bank for International Settlements (ed.), Transmission Mechanisms for Monetary Policy in Emerging Market Economies, Vol. 35, pp. 1-59 (Basle: Bank for International Settlements). 
Moreno, Ramon, 2008, "Monetary Transmission Mechanism and Long Term Interest Rate in Emerging Markets,” BIS Papers, chapter in Bank for International Settlements (ed.), Transmission Mechanisms for Monetary Policy in Emerging Market Economies, Vol. 35, pp. 1-59 (Basle: Bank for International Settlements).

Peiris, S. J., 2010, “Foreign Participation in Emerging Markets’ Local Currency Bond Markets,” IMF Working Paper 10/88 (Washington: International Monetary Fund).

Pradhan, M., R. Balikrishnan, R. Baqir, G. Heenan, S. Nowak, C. Oner, and S. Panth, 2011, "Policy Responses to Capital Flows in Emerging Markets," Paper for the Bank of Indonesia and IMF Joint Conference on Coping With Asia's Large Capital Inflows in a Multi-Speed Global Economy (Washington: International Monetary Fund).

Unsal, D. Filiz, 2012, "Capital Flows and Financial Stability: Monetary Policy and Macroprudential Responses," International Journal of Central Banking, forthcoming.

Warnock, F. E., and V. C. Warnock, 2009, "International Capital Flows and U.S. Interest Rates," Journal of International Money and Finance, Vol. 28, pp. 903-19. 